DOI: $10.34185 / 1991-7848.2021 .01 .03$

УДК 530.1

А.О. Журба ${ }^{3}$

\title{
ДОСЛІДЖЕННЯ ВПЛИВУ КРИСТАЛІЧНИХ РЕШІТОК НА ФРАКТАЛЬНІ ХАРАКТЕРИСТИКИ МАТЕРІАЛІВ
}

\begin{abstract}
Значний інтерес представляють кристалічні тіла, які характеризуються впорядкованим розташуванням атомів. До кристалів можна віднести мінерали, всі метали, солі, більшість органічних сполук і велику кількість інших твердих тіл. Закономірна і досконала геометрія кристалів говорить про наявність закономірностей і в їх внутрішній будові. Ці впорядковані структурні частинки, що розташовані правильними рядами в строгій ієрархічній послідовності і мають ось симетрії другого, третього, четвертого $і$ шостого порядків. Строго математично доведено, що відмічені порядки осей в тому або іншому поєднанні для кристалів єдино можливі. Інших порядків осей симетрії, поворот навколо яких переводив би грати кристала самі в себе, в класичній кристалографії не існує. Томує сенс побудувати поверхні другого, третього, четвертого порядків симетрії та провести аналіз їх фрактальних характеристик. Цікавим дослідженням $\epsilon$ побудова фрактальних розподілень таких поверхонь.
\end{abstract}

Ключові слова: фрактальна розмірність, фрактальні розподілення, кристалічна решітка, квазікристали, шехтманіт, обертальна симетрія, порядок симетрії, мозаїка Пенроуза, кристалічна та квазікристалічна фрактальна поверхня.

\section{Постановка проблеми та аналіз останніх досліджень}

Структуру твердих тіл в природі можна розділити на три класи: 1. невпорядковані аморфні тіла, в яких повністю відсутня закономірність у взаємному розташуванні атомів; 2. кристалічні тіла, що характеризуються їх впорядкованим розташуванням; 3. квазікристали, що розглядаються як проміжні форми між аморфними і кристалічними тілами [1].

До кристалів можна віднести мінерали, всі метали, солі, більшість органічних сполук і велику кількість інших твердих тіл. Закономірна i досконала геометрія кристалів говорить про наявність закономірностей і в їх внутрішній будові. Ці впорядковані структурні частинки, що розташовані правильними рядами в строгій ієрархічній послідовності, визначають просторові кристалічні грати і мають ось симетрії другого, третього, четвертого і шостого порядків. Строго математично доведено, що відмічені порядки осей в тому або іншому поєднанні для кристалів єдино можливі. Інших порядків осей симетрії, поворот навколо яких переводив би грати кристала самі в себе, в класичній кристалографії не існує.

() Журба А.О., 2021 
У 1984 році Д. Шехтманом був відкритий сплав алюмінію 3 марганцем 3 незвичайними властивостями. Він мав структуру схожу на кристал, але їм не був, оскільки мав обертальну симетрію 5-го порядку. Виявлена структура згодом була названа шехтманітом. Наявність різких дифракційних максимумів свідчила про впорядковане розташування атомів в структурі, що характерна для кристалів, а наявність осі симетрії 5-го порядку, що спостерігалася, суперечила фундаментальним представленням класичної кристалографії i говорила про те, що досліджувана речовина не є кристалом. Така структура отримала назву квазікристала.

Моделлю двовимірного квазікристала є мозаїка Пенроуза, що являє собою впорядковану структуру, яка складається з двох ромбів з рівними сторонами. Така мозаїка має багато властивостей, характерних для квазікристалічного стану речовини [2].

Тому є сенс побудувати поверхні другого, третього, четвертого, п’ятого та шостого порядків симетрії та провести аналіз їх фрактальних характеристик. Цікавим дослідженням $є$ побудова фрактальних розподілень таких поверхонь.

Метою цієї роботи $\epsilon$ розробка програмних модулів для побудови квазікристалічних та кристалічних решіток 3 симетрією різних порядків; обчислення фтактальних розмірностей та побудова фрактальних розподілень природних та комп’ютерних поверхонь кристалів і квазікристалів.

\section{Викладення основного матеріалу дослідження}

B ході дослідження розроблено програмний продукт PenrouseFS, який дозволяє побудувати фрактальні поверхні на кристалічних решітках з різною поворотною симетрією та на квазікристалічних решітках. Побудовані фрактальні поверхні кристалічних та квазікристалічних структур за допомогою метода випадкового зсуву середньої точки. Даний метод розпочинається 3 трикутника, що лежить у довільній площині. Середні точки сторін трикутника з'єднанні між собою таким чином, що трикутник виявляється поділеним на чотири менші трикутники. Після чого кожна середня точка зсувається вгору або вниз на певну, випадково обрану величину. Такий самий процес застосовується до кожного з менших трикутників, потім до ще менших й так далі нескінченно [3]. Етапи побудови фрактальної поверхні наведені на рис. 1.

у цьому методі зсуву середніх точок випадкові величини для переміщення середніх точок угору або вниз керуються певним законом розподілу, який підбирається, щоб отримати близьку апроксимацію бажаної поверхні. Таким чином, за допомогою методу зсуву середньої точки 3 кристалічної решітки можна створювати фрактальні складні поверхні з певною поворотною симетрією. Було досліджено, що у всіх поверхонь, побудованих даним методом існує загальна властивість: міра порізаності або складності їх структури вимірюється фрактальною розмірністю. 

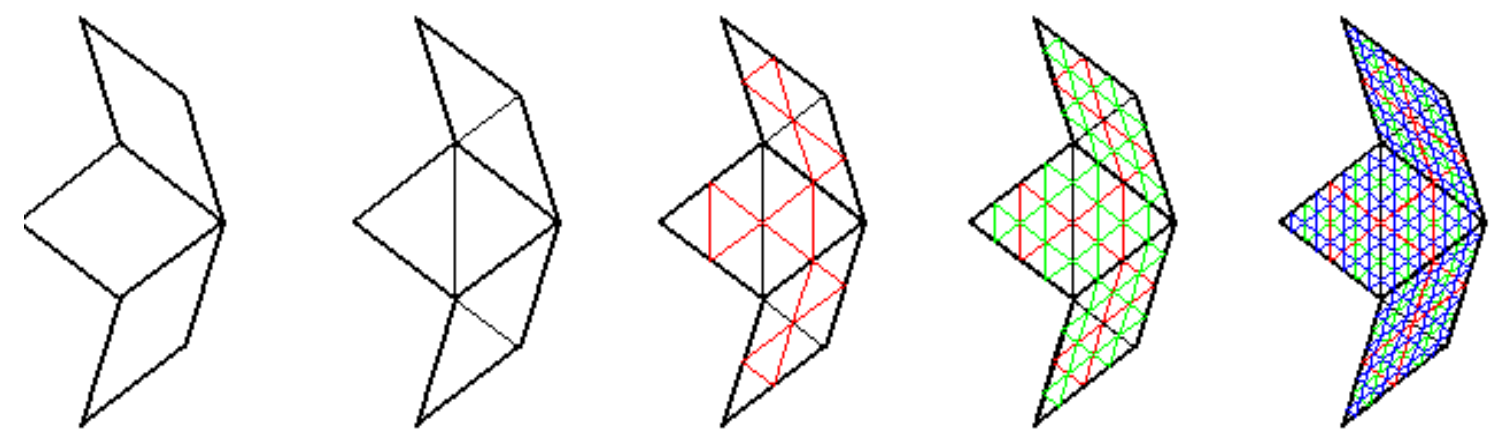

Рисунок 1 - Етапи побудови фрактальних поверхонь

на прикладі елементів мозаїки Пенроуза

В ході роботи було побудовано чисельну кількість фрактальних поверхонь кристалічних та квазікристалічних структур 3 використанням наведеного методу: побудовані кристалічні структури другого, третього, четвертого, шостого порядків симетрії та квазікристалічні структури з різною кількістю ітерацій (від 4 до 9), яка відповідає за ступінь деталізації поверхні та проведений аналіз їх фрактальних характеристик. При цьому побудова поверхні розпочиналася 3 розбиття початкової кристалічної решітки, що представлена квадратами (для кристалічної структури другого порядку) чи прямокутниками (для кристалічної структури четвертого порядку) на два трикутники, до яких було застосовано метод випадкового зсуву середньої точки. Початкові кристалічні решітки для побудови фрактальних поверхонь представлені на рис. 2.

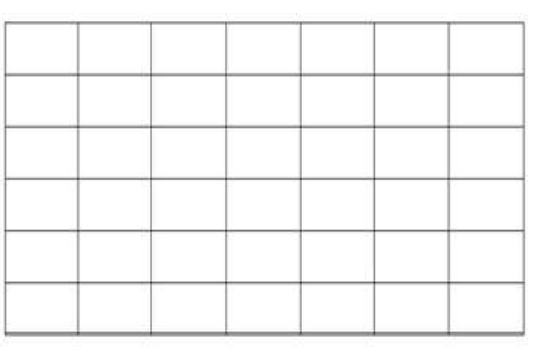

a)

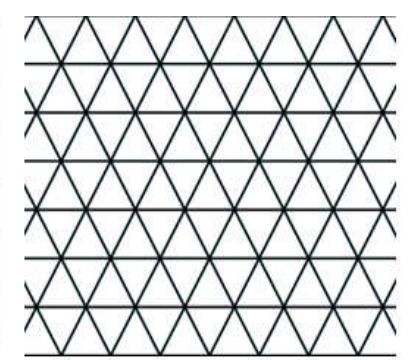

б)

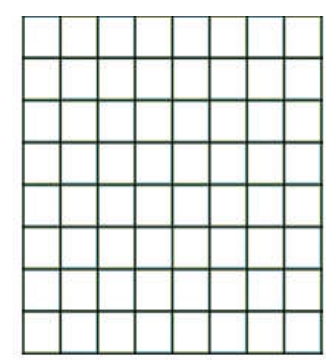

B)

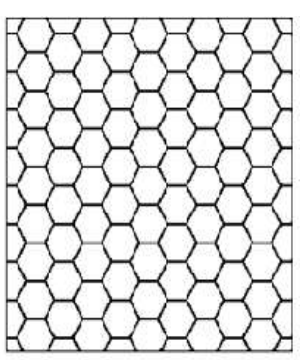

г)

Рисунок 2 - Кристалічна решітка другого (а), третього (б), четвертого (в) та шостого (г) порядків обертальної симетрії

За допомогою розробленого програмного продукту було побудовано чотири види фрактальних поверхонь на кристалічних решітках другого, третього, четвертого та шостого порядків обертальної симетрії з кількістю ітерацій від чотирьох до дев’яти. На рис. 3 наведено отримані фрактальні поверхні. 3 представлених на рис. 3 кристалічних поверхонь можна побачити кристалічну решітку, що бралася за основу при побудові поверхні. 


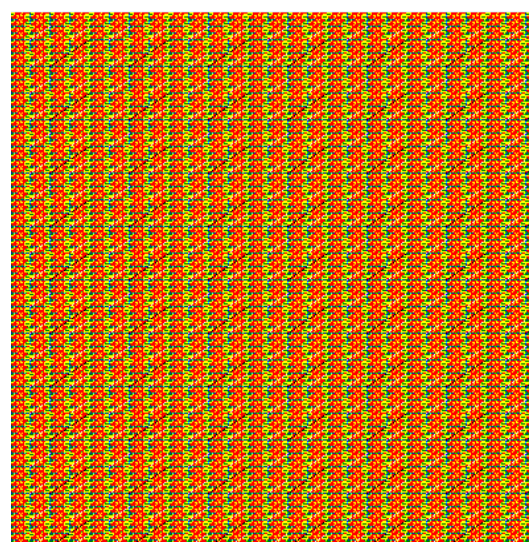

a)

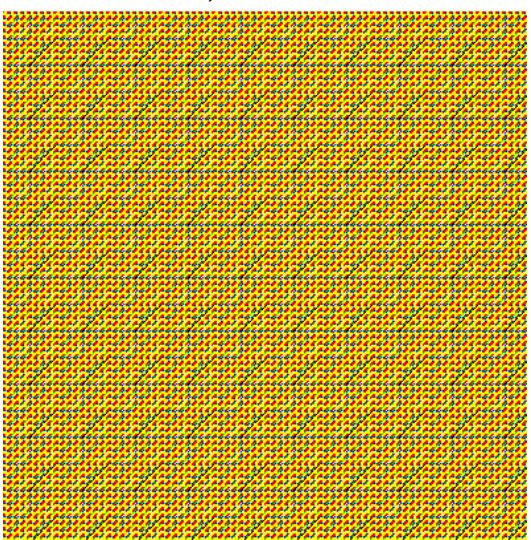

B)

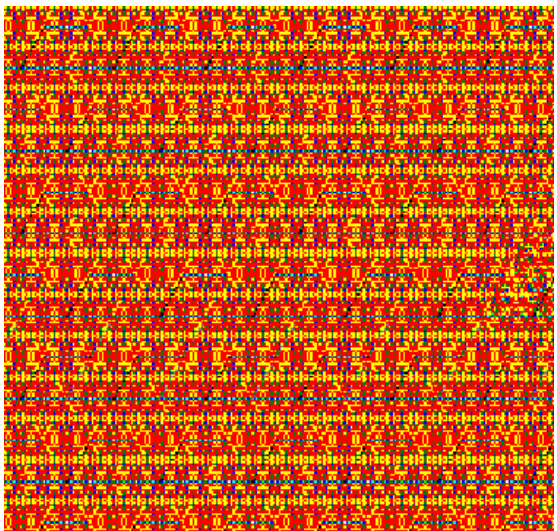

б)

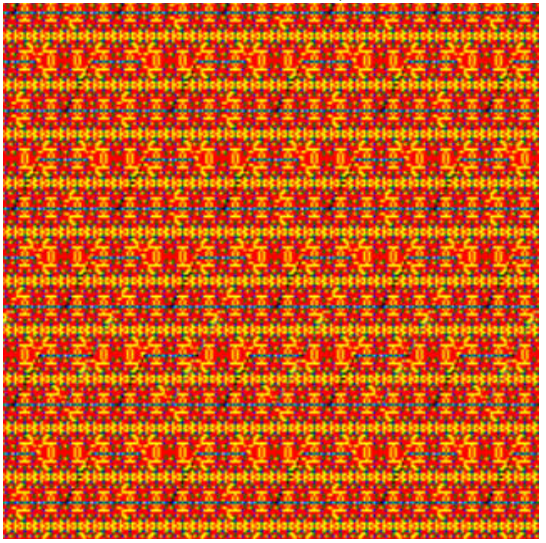

$\Gamma)$

Рисунок 3 - Кристалічні поверхні з орієнтаційною симетрією другого (а), третього (б), четвертого (в) і шостого (г) порядків

Поверхні квазікристалічних структур - поверхні Пенроуза - були побудовані на основі мозаїк Пенроуза з використанням методу випадкового зсуву середньої точки. При цьому побудова поверхні розпочиналася з розбиття кожного з ромбів, якими представлена мозаїка Пенроуза, на два трикутники, до яких було застосовано метод випадкового зсуву середньої точки. Доцільність побудови поверхонь Пенроуза зумовлена властивістю самоподібності мозаїки Пенроуза, яка являє собою модель квазікристалу. Початкова квазікристалічна решітки для побудови фрактальних поверхонь представлена на рис. 4.

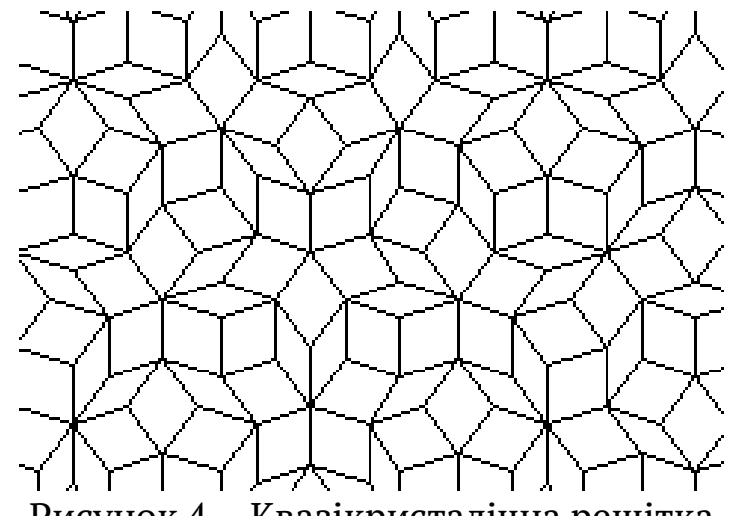

Рисунок 4 - Квазікристалічна решітка 
На рис. 5 наведено приклад квазікристалічної поверхні з обертальною симетрією п’ятого порядку.

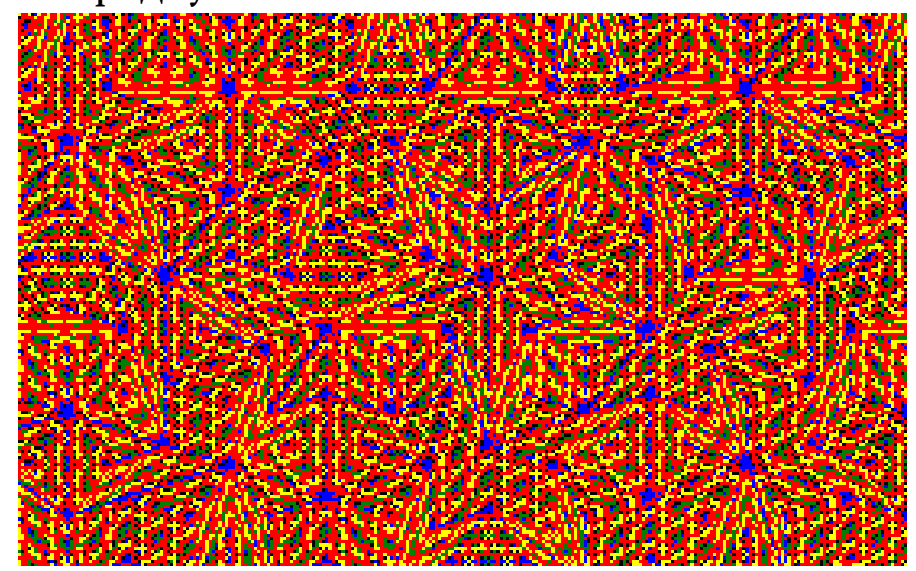

Рисунок 5 - Квазікристалічна фрактальна поверхня 3 обертальною симетрією п'ятого порядку

На рис. 6 представлені зображення фрактальної поверхні 3 кількістю ітерацій 4 та 9. Зображення представлені у чорно-білих кольорах, де чорним кольором зазначені області, що не підлягали обробці алгоритмом (найнижчі точки), білим кольором - найвищі точки. 3 рис. 6 видно, що чим більша кількість ітерацій, тим більше білих точок на зображені і тим точніше деталізація поверхні.

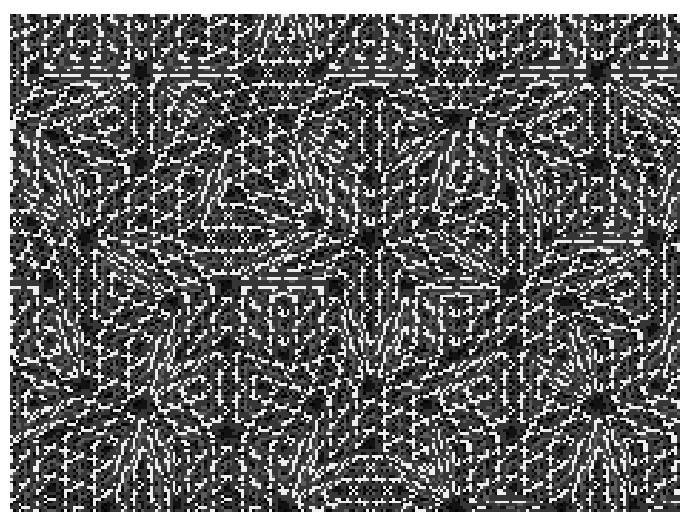

a)

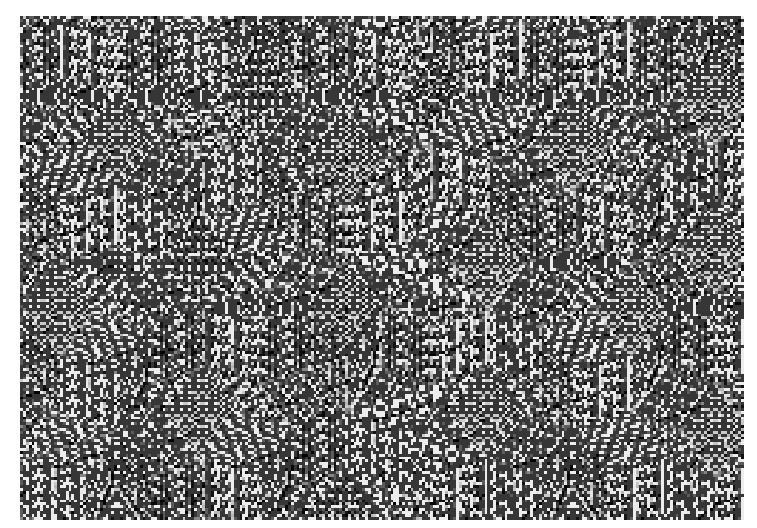

б)

Рисунок 6 - Приклад фрактальної поверхні на основі мозаїки Пенроуза з різною деталізацією (рисунок інверсовано): а) кількість ітерацій - 4; б) кількість ітерацій - 9

\section{Дослідження кристалічних поверхонь, що згенеровані}

\section{за допомогою комп'ютерної програми PenroseFS}

Для зображень побудованих поверхонь кристалічних та квазікристалічних структур було проведено фрактальний аналіз, що складається із визначення фрактальної розмірності та побудови фрактальних розподілень. Фрактальна розмірність визначалася з використанням методу BOX COUNTING, який $є$ найбільш універсальним та дозволяє працювати із зображеннями будь-якої структури. Для отримання фрактальних розподілень використовується метод 
ковзаючого вікна, який полягає у визначенні фрактальної розмірності в межах вікна, розмір якого можна задавати довільно. Вікно попіксельно переміщується по зображенню. При цьому на кожному кроці обчислюється фрактальна розмірність зображення, що потрапило у ковзаюче вікно. Після чого проводиться побудова їх емпіричного розподілу ймовірностей $W(D) / W \max (D)$. Складні зображення після обчислення фрактальних розподілень дають багатомодальні розподіли.

Аналіз кристалічних поверхонь з симетрією різних порядків дозволив визначити їх фрактальні розмірності, побудувати розподілення локальних фрактальних розмірностей. В ході дослідження було визначено зростання фрактальної розмірності із збільшенням кількості ітерацій. При цьому відзначено майже на всіх видах поверхонь незначне зниження значень фрактальної розмірності при кількості ітерацій, що дорівнюють 5 та 6 (табл. 1). Найменше значення фрактальної розмірності при найменшій деталізації поверхні.

Таблиця 1

Фрактальна розмірність кристалічних поверхонь з різним ступенем деталізації

\begin{tabular}{|l|l|l|l|l|l|l|}
\hline \multirow{2}{*}{$\begin{array}{l}\text { Порядок симетрії } \\
\text { кристалічної поверхні }\end{array}$} & \multicolumn{6}{|l}{ Значення фрактальної розмірності поверхні при побудові в } \\
\cline { 2 - 7 } & 4 & 5 & 6 & 7 & 8 & 9 \\
\hline 2-го порядку & 1,65 & 1,81 & 1,86 & 1,79 & 1,85 & 1,87 \\
\hline 3-го порядку & 1,58 & 1,73 & 1,75 & 1,67 & 1,72 & 1,74 \\
\hline 4-го порядку & 1,72 & 1,85 & 1,85 & 1,87 & 1,85 & 1,85 \\
\hline 6-го порядку & 1,59 & 1,72 & 1,75 & 1,68 & 1,72 & 1,75 \\
\hline
\end{tabular}

На рис. 7 наведено графік зміни значень фрактальної розмірності в залежності від ступеню деталізації поверхні. 3 графіку видно, що найбільші значення фрактальної розмірності мають кристалічні поверхні 4-го порядку симетрії. Кристалічні поверхні 3-го та 6-го порядку симетрії мають дуже близькі значення фрактальної розмірності. При цьому їх значення фрактальної розмірності менші за кристалічні поверхні 2-го та 4-го порядку симетрії.

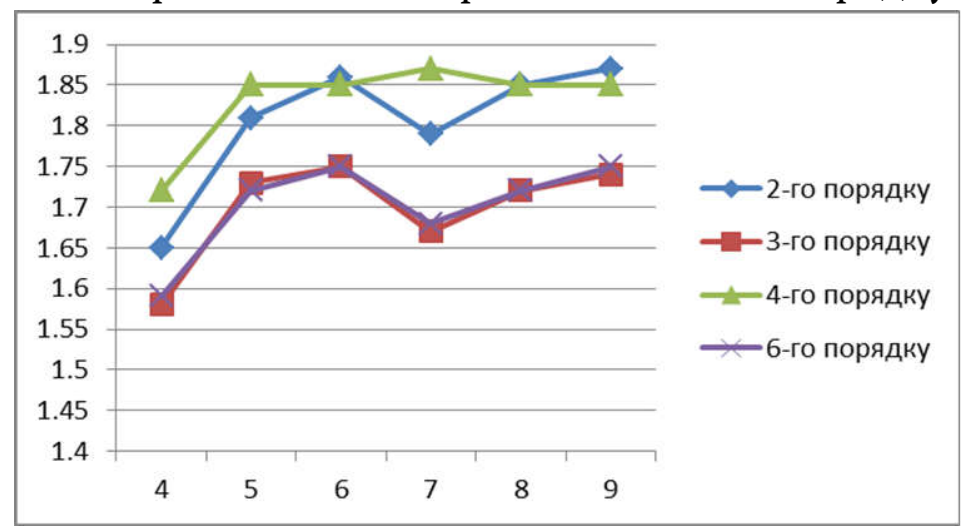

Рисунок 7 - Графік зміни значень фрактальної розмірності в залежності від ступеню деталізації поверхні 
Результати досліджень кристалічних структур наведено в табл. 2, з якої видно, що фрактальні розподілення майже для всіх видів поверхонь мають багатомодальний розподіл і широкий розкид значень фрактальної розмірності, який вказує на складні зображення. Фрактальне розподілення кожної із побудованих поверхонь має кількість мод, яка співпадає з порядком симетрії. Таким чином, фрактальні методи дозволяють визначати порядок обертальної симетрії кристалічних матеріалів.

Таблиця 2

Фрактальна розмірність та фрактальні розподілення поверхонь 3 орієнтаційною симетрією другого, третього, четвертого та шостого порядків

\begin{tabular}{|l|l|}
\hline Зображення поверхні & Фрактальні розподілення \\
\hline Симетрія 2-го порядку \\
2 моди розподілення
\end{tabular}




\section{Дослідження природних поверхонь кристалічних матеріалів на прикладі сніжинок}

Будь-яка сніжинка завжди має шість променів. Така форма зумовлена молекулярною будовою води. Вона складається з атома кисню і двох атомів водню. Кожна молекула води є трикутник. Кристали льоду мають форму шестикутника, який складається з таких трикутників (рис. 8а). Цей найперший кристалик і є майбутня сніжинка. Далі він росте за рахунок приєднання нових молекул до кристалику рис. 8б).

Порядок приєднання нових молекул випадковий, але в підсумку вони шикуються в шестигранники, такі ж, як і перший кристалик (рис. 8в).

Далі у сніжинки почнуть рости відгалуження. Як саме вони будуть виглядати, залежить від температури, вологості, тиску та інших факторів. Кристалики приєднуються один до одного завжди гранню і ніколи кутом, тому промінь сніжинки завжди буде шестикутним (рис. 8г).

Від променя можуть відходити гілки, але вони завжди будуть рости під кутом $60^{\circ}$ або $120^{\circ}$ рис. 8д). Так має виглядати ідеальна сніжинка. У реальності величезне скупчення «гілок», які приростають у випадковому порядку, робить кожну сніжинку унікальною [4].

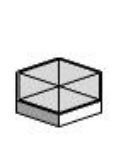

a)

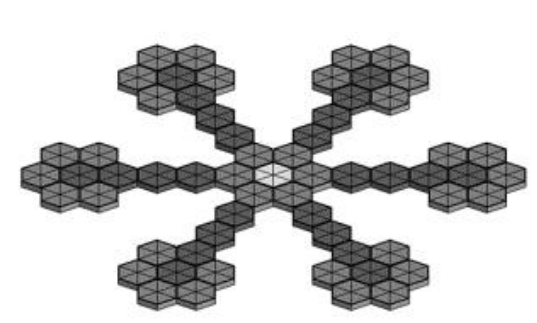

г)

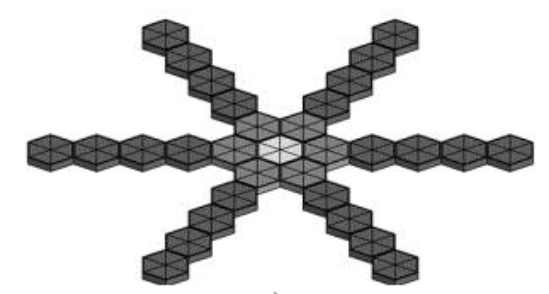

B)

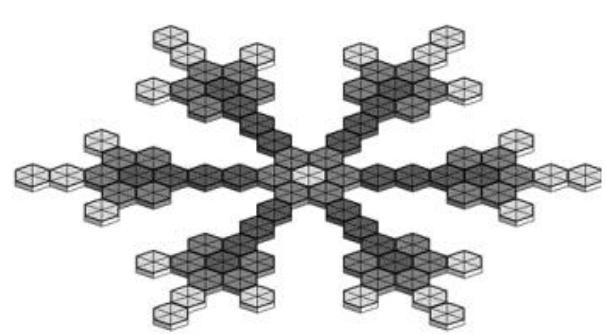

д)

Рисунок 8 - Процес побудови сніжинки

Розглядаючи сніжинки, можна помітити, що жодна з них не повторює іншу. Передбачається, що в одному кубічному метрі снігу знаходиться 350 мільйонів сніжинок, кожна 3 яких унікальна. Не буває п'ятикутних чи семикутних сніжинок, всі вони мають строго шестикутну форму.

У 1951 році Міжнародна Комісія з Снігу і Льоду прийняла класифікацію твердих опадів. Відповідно до неї всі снігові кристали можна розділити на наступні групи: зірчасті дендрити, пластинки, стовпці, голки, просторові дендрити, стовпці з наконечником і неправильні форми. До них додалися ще три види обледеніли опадів: дрібна снігова крупка, крижана крупа і град. 
При дослідженні фрактальних властивостей було проаналізовано близько 50 зображень різноманітних сніжинок, що відносяться до різних груп. При дослідженні фрактальна розмірність мікроструктур визначалася методом BOX COUNTING. Для побудови фрактальних розподілень використовувався метод ковзаючого вікна.

При обчислені фрактальних властивостей сніжинок було проаналізовано ряд зображень з різними типами сніжинок. В табл. 3-4 представлені результати обчислень фрактальних характеристик сніжинок типу «Пластинки» та типу «Зірчасті дендріти». Для кожного зображення було обчислено фрактальні розмірності та побудовано фрактальні розподілення.

В табл. 3 представлені фрактальні характеристики сніжинок типу «Пластинки». Пластинки - безліч крижаних ребер як ніби ділять лопаті сніжинок на сектора. Вони плоскі і тонкі.

В результаті дослідження було виявлено, що для групи сніжинок «Пластинки» діапазон значень фрактальної розмірності від 1.54 до 1.81, а кількість мод розподілення 6.

Таблиця 3

Фрактальні характеристики сніжинок типу «Пластинки»

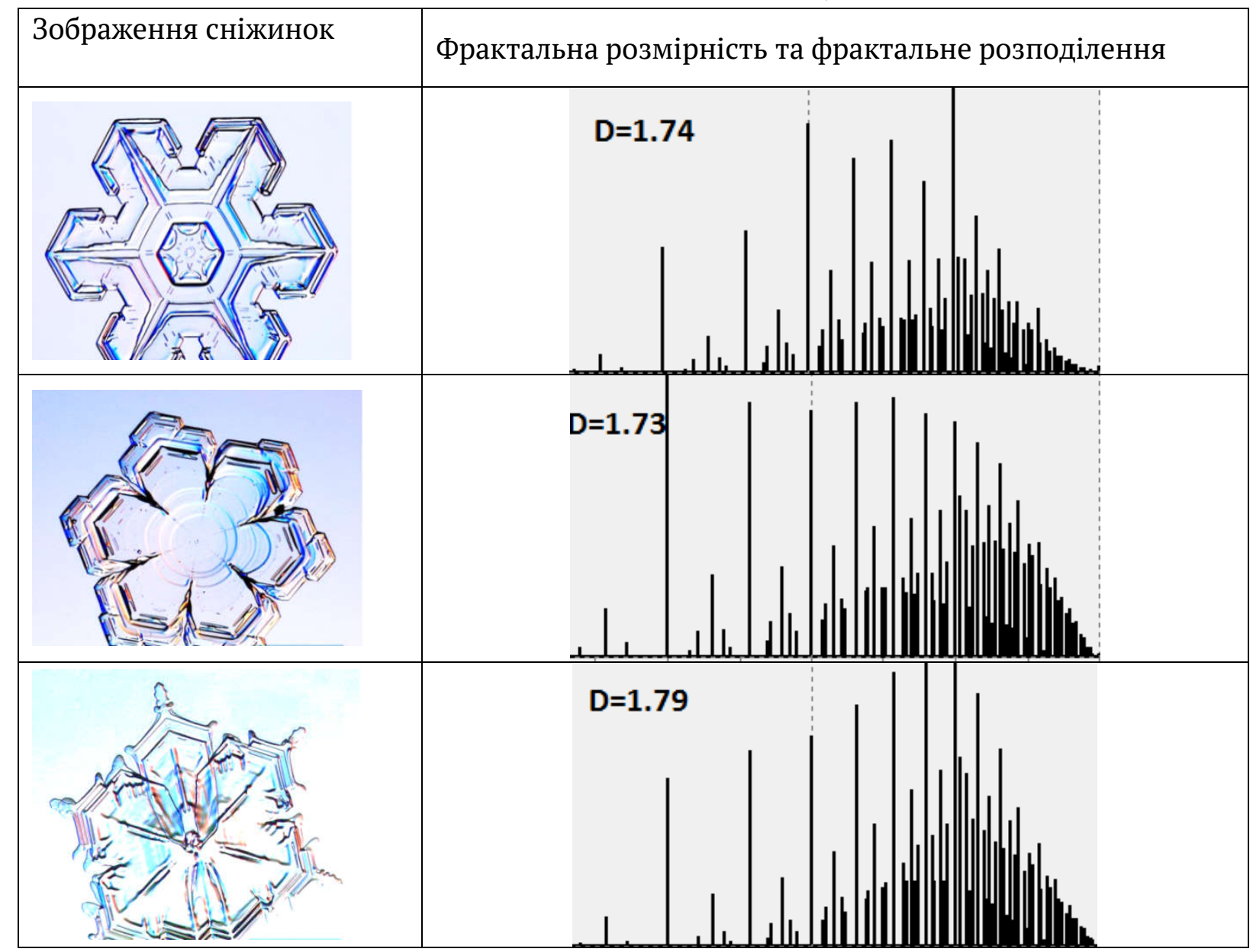


У таблиці 4 представлені фрактальні характеристики сніжинок типу «Зірчасті дендрити». Зірчасті дендрити - кристал або інше утворення, що має деревоподібну структуру. Вони мають шість симетричних основних гілок i безліч розташованих в довільному порядку відгалужень. Їх розмір - 5 мм і більше в діаметрі, як правило, вони плоскі і тонкі - всього 0.1 мм.

В результаті дослідження було виявлено, що для групи сніжинок «Зірчасті дендрити» діапазон значень фрактальної розмірності від 1.55 до 1.72, а кількість мод розподілення 6.

Таблиця 4

Фрактальні характеристики сніжинок типу «Зірчасті дендрити»

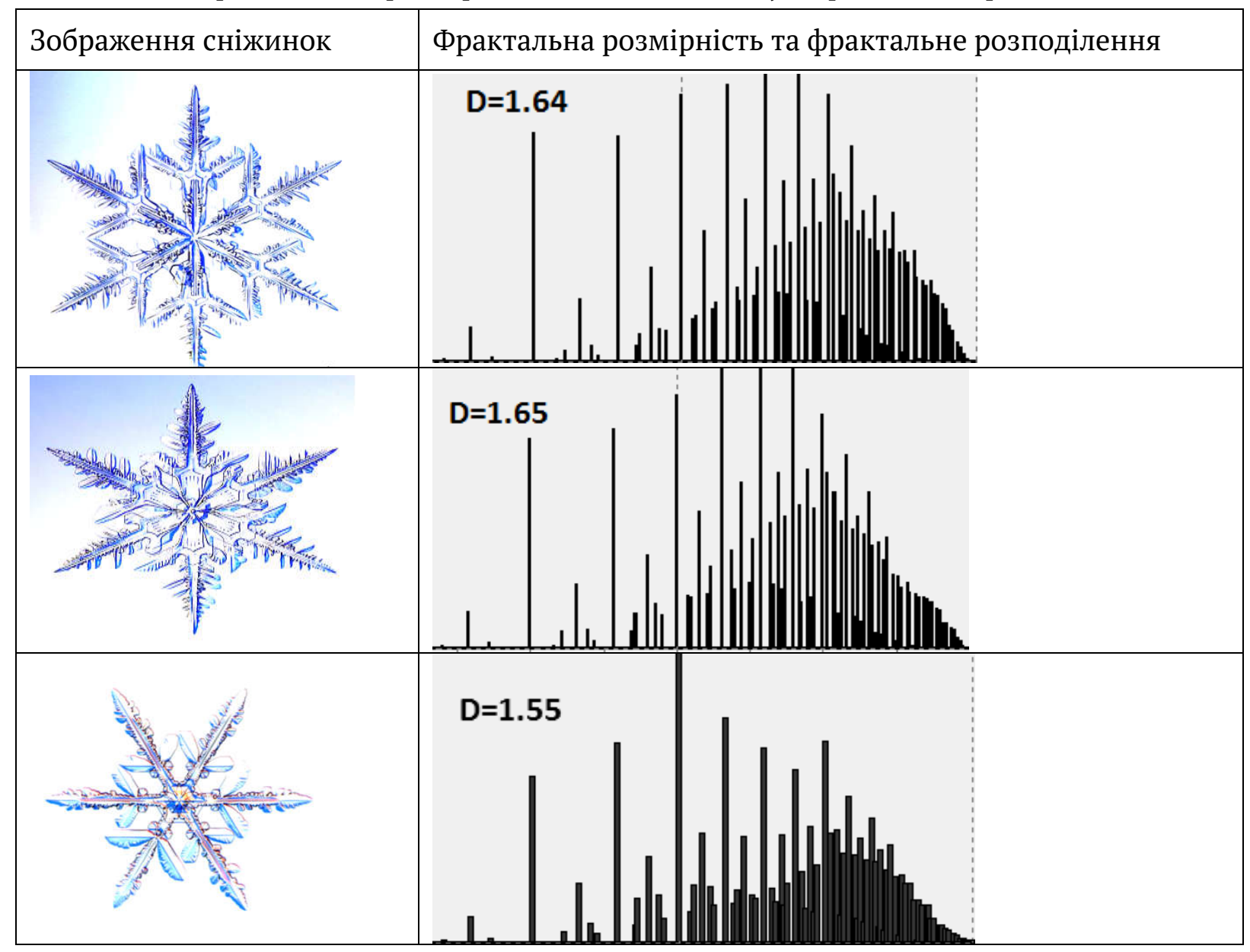

\section{Дослідження комп’ютерної поверхні квазікристалів}

На рис. 9 представлено зображення поверхні Пенроуза, наведено її фрактальні розмірності при кількості ітерацій від чотирьох до дев'яти та побудовано графік залежності фрактальної розмірності від кількості ітерацій, на яких по осі абсцис відкладена кількість ітерацій, а по осі ординат - значення фрактальної розмірності. Графік дає можливість прослідкувати зростання фрактальної розмірності із збільшенням кількості ітерацій. При цьому 
спостерігається незначне зниження значень фрактальної розмірності при кількості ітерацій, що дорівнюють 5 та 6.

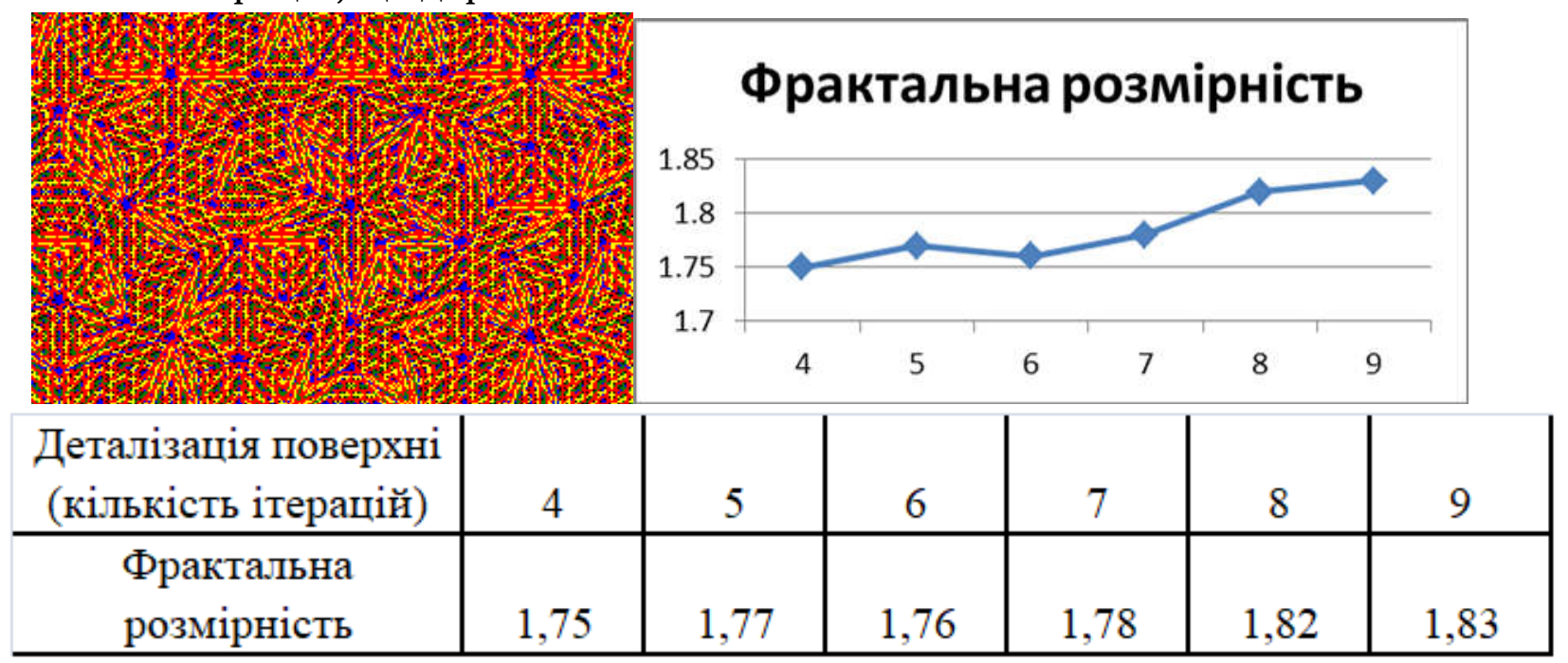

Рисунок 9 - Залежність фрактальної розмірності поверхні Пенроуза від кількості ітерацій

На рис. 10 представлено фрактальне розподілення квазікристалічної поверхні Пенроуза. Фрактальне розподілення наведено для поверхоні лише при кількості ітерацій, що дорівнює 9, оскільки розподіл локальних фрактальних розмірностей від кількості ітерацій істотно не змінюється. Цей факт говорить про те, що від більшої деталізації поверхні їі основні властивості залишаються незмінними.

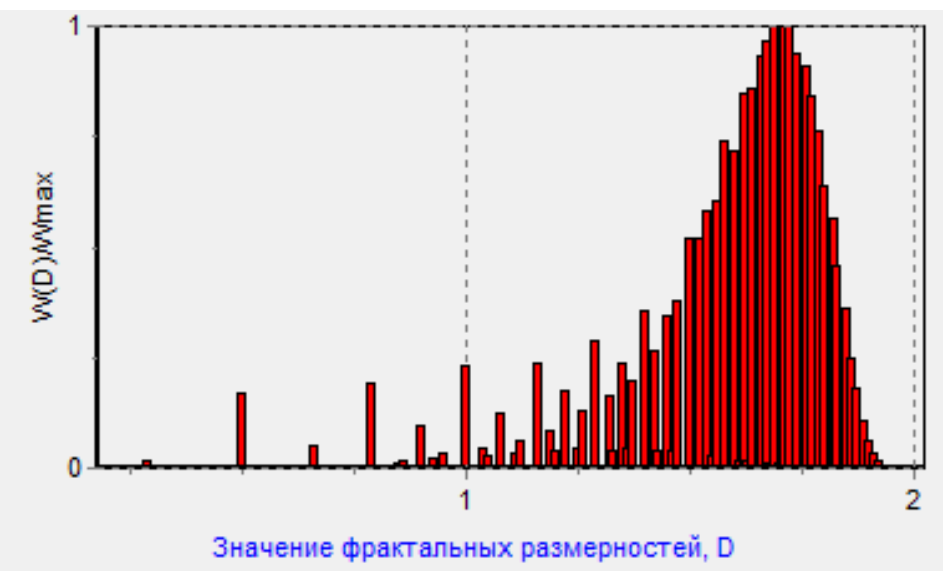

Рисунок 10 - Розподілення локальних фрактальних розмірностей поверхонь Пенроуза

3 рис. 9 видно, що фрактальне розподілення квазікристалічної поверхні має багатомодальний розподіл і широкий розкид значень фрактальної розмірності, який вказує на складне зображення. Кожна мода такого розподілу відповідає кластеру зображення, що має близькі значення локальних розмірностей. При цьому слід відзначити, що фрактальне розподілення будьякої із квазікристалічних поверхонь Пенроуза має п’ять таких мод. Це вказує 
на обертальну симетрію п'ятого порядку, яку має мозаїка Пенроуза, а отже - i квазікристалічні поверхні.

\section{Дослідження природної поверхні квазікристалу}

Раніше вважалося, що кристалічні речовини не можуть володіти симетрією 5-го порядку. Поширеність же цього типу симетрії у рослин і у голкошкірих використовували як свідчення того, що життя являє якісно інший рівень організації. У 1984 році було зроблено відкриття в мінералогії: виявилося, що метали в склоподібному стані являють собою новий вид впорядкованості атомів. Вони ні кристалічні, ні повністю аморфні; їх назвали квазікристалами. Швидко охолоджений зразок шехтманіта - сплаву алюмінію 3 марганцем - володіє симетрією 5-го порядку. Таку ж симетрію можна отримати i у багатьох інших металів. Шехтманом, якщо його розплавити і швидко охолодити, утворює гіллясті структури, схожі на снігові пластівці. Однак квазікристали шехтманіта, на відміну від кристалів льоду, мають симетрію не 6-го, а 5-го порядку.

На рис. 11 наведено зображення квазікристалу шехтманіту та наведено зображення фрактального розподілення квазікристалу шехтманіту, яке має 5 мод розподілення. Таку ж кількість мод розподілення мають і квазікристалічні поверхні, згенеровані комп'ютерним шляхом. Фрактальна розмірність квазікристалу шехтманіту має таке ж значення як і комп’ютерна модель квазікристалічної поверхні при найвищому ступені деталізаціі.
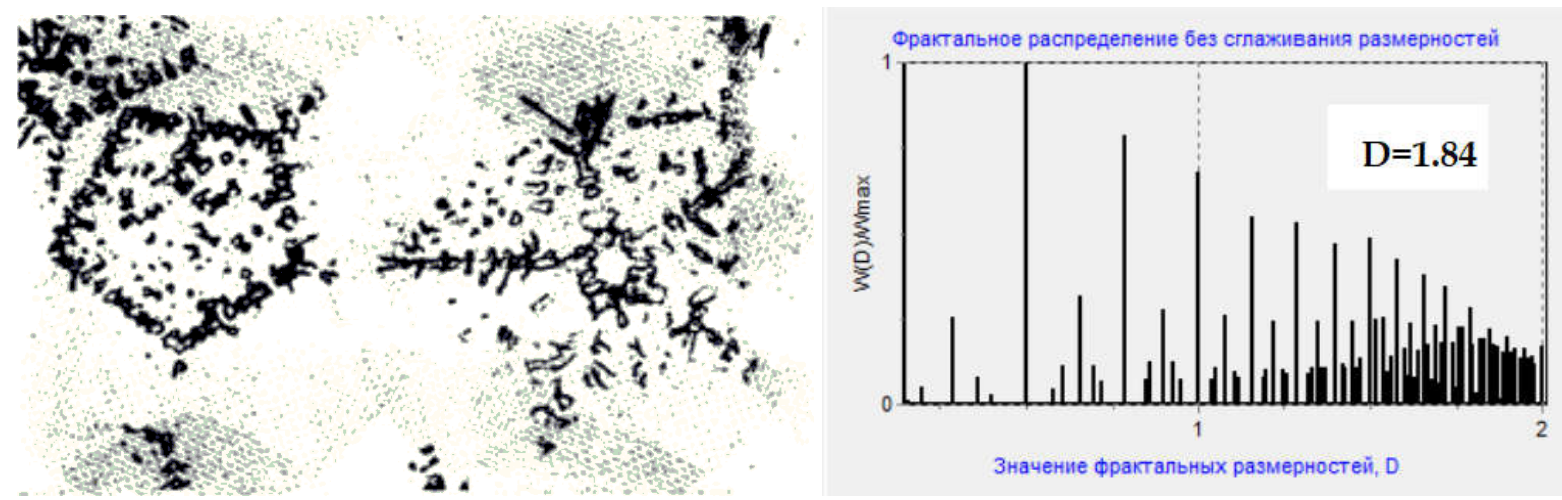

Рисунок 11 - Квазікристал шехтманіту. Фрактальне розподілення та фрактальна розмірність квазікристалу шехтманіту

\section{Висновки}

В роботі були досліджені природні та комп’ютерні кристалічні та квазікристалічні фрактальні поверхні. Для кожної поверхні було обчислено фрактальну розмірність та побудовано фрактальне розподілення. В ході досліджень було виявлено, що фрактальні розподілення майже для всіх видів кристалічних та квазікристалічних поверхонь мають багатомодальний 
розподіл і широкий розкид значень фрактальної розмірності, який вказує на складні зображення. Фрактальне розподілення кожної із побудованих поверхонь має кількість мод, яка співпадає з порядком симетрії.

\section{ЛІТЕРАТУРА}

1. Журба А.О. Визначення порядку обертальної симетрії кристалічних та квазікристалічних матеріалів з використанням фрактального аналізу / А.О. Журба // Сучасні проблеми металургії. - №16. Дніпропетровськ. - 2013. - С. 63-68.

2. Журба А.О. Дослідження фрактальних властивостей сніжинок / А.О. Журба, Д.І. Журба, О.І. Михальов, О.І. Дерев'янко // Системні технології. Регіональний міжвузівський збірник наукових праць. - Випуск 4 (111). - Дніпро. - 2017. - С. 12-21.

3. Журба А.О., Михальов О.І. Фрактальні характеристики зображень металоструктур та особливості ї обчислення // Системные технологии моделирования сложных систем / Монография под общей редакцией проф. А.И. Михалёва. - Днепр: НМетАУ-ИВК “Системные технологии", 2016. - С. 299 - 327. ISBN 978-966-2596-19-9.

4. Журба А.О., Пластун Б.О. Дослідження впливу кристалічної решітки на фрактальні розподілення металевих матеріалів // Сучасні інформаційні та комунікаційні технології на транспорті, в промисловості i освіті: Тези XIV Міжнародної науково-практичної конференції (Дніпро, 15-16 грудня 2020 р.). - Д.: ДІІТ, 2020. - С. 81.

\section{REFERENCES}

1. Zhurba A.O. Determination of the order of rotational symmetry of crystalline and quasi-crystalline materials using fractal analysis / A.O. Zhurba // Modern problems of metallurgy. - №16. Dnipropetrovsk. - 2013. - P. 63-68.

2. Zhurba A.O. Investigation of fractal properties of snowflakes / A.O. Zhurba, D.I. Zhurba, O.I. Mikhalov, O.I. Derevyanko // System technologies. Regional interuniversity collection of scientific works. - Issue 4 (111). - Dnipro. - 2017. - P. 12-21.

3. Zhurba A.O., Mikhalev O.I. Fractal characteristics of images of metal structures and features of their calculation // System technologies of modeling complex systems / Monograph under the general editorship of prof. A.I. Mikhaleva. - Dnipro: NMetAU-IVK “System Technologies”, 2016. P. 299 - 327. ISBN 978-966-2596-19-9.

4. Zhurba A.O., Plastun B.O. Investigation of the influence of a crystalline lattice on fractal distributions of metal materials // Modern information and communication technologies in transport, industry and education: Abstracts of the XIV International Scientific and Practical Conference (Dnipro, December 15-16, 2020). - D.: DIIT, 2020. - P. 81.

Received 13.01.2021. Accepted 26.01.2021.

UDC 530.1

A. Zhurba

\section{INVESTIGATION OF THE INFLUENCE OF CRYSTALLINE LATTICES ON FRACTAL CHARACTERISTICS OF MATERIALS}

In the work, natural and computer crystalline and quasi-crystalline fractal surfaces were investigated. For each surface, fractal dimension was calculated and fractal distribution was constructed.

During the study, PenrouseFS software is developed, which allows the fractal surfaces on crystalline grates with different rotary symmetry and quasi-crystalline lattices. The fractal surfaces of crystalline and quasi-crystalline structures are constructed using a random shear method. 
In the course of the work, a numerical number of fractal surfaces of crystalline and quasi-crystalline structures was built using the given method: the crystalline structures of the second, third, fourth, sixth, sixth forms of symmetry and quasi-crystalline structures with a different number of iterations (from 4 to 9), which are responsible for the degree of surface detailation, was constructed. and analyzed their fractal characteristics.

Analysis of crystalline surfaces with symmetry of different orders allowed to determine their fractal dimensions, to construct the distribution of local fractal dimensions. During the study, the growth of fractal dimension with an increase in the number of iterations was determined. In almost all types of surfaces, a slight decrease in the values of fractal dimension in the amount of iterations equal to 5 and 6 . is the smallest value of fractal dimension with the smallest detail of the surface.

The greatest values of fractal dimension have crystalline surfaces of the 4 th order of symmetry. The crystalline surfaces of the 3rd and 6th order of symmetry have very close fractal dimensions. In this case, their value of fractal dimension is smaller than the crystalline surfaces of the 2 nd and 4 th order of symmetry.

In the study of fractal properties, about 50 images of a variety of snowflakes belonging to different groups were analyzed. In the study, the fractal dimension of microstructures was determined by the Box Couning method. To construct fractal distributions, a method of sliding window was used.

When calculated fractal properties of snowflakes, a number of images of "plates" and "Star Dendrites" type were analyzed. As a result of the study, it was found that for a group of snowflakes "Plates" range of fractal dimension values from 1.54 to 1.81 , and the number of modification modes 6, and for the group of snowflakes "Star Dendrid" range of fractal dimension values from 1.55 to 1.72, and the number of modification modes 6 .

The image of the Quasi crazi-crazinite has 5 modes of distribution. The same amount of distribution mods have a quasi-crystalline surfaces of pentroose generated by a computer route. The fractal dimension of the quasi-crystal of shekhtmanite has the same meaning as a computer model of a quasi-crystalline surface at the highest degree of detail.

During the research, it has been found that fractal distributions almost for all types of crystalline and quasi-crystalline surfaces have a multimodal distribution and a wide spread of fractal dimension values, which indicates complex images. Fractal distribution of each of the built surfaces has a number of mods that coincides with the order of symmetry.

Keywords: fractal dimension, fractal distributions, crystal lattice, quasicrystals, Schechtmanite, rotational symmetry, symmetry order, Penrose mosaic, crystalline and quasicrystalline fractal surface.

Журба Анна Олексіївна - к.т.н., доцент, доцент кафедри інформаційних технологій і систем, Національна металургійна академія України.

Журба Анна Алексеевна - к.т.н., доцент, доцент кафедри информационных технологий и систем, Национальная металлургическая академия Украины.

Zhurba Anna - candidate of technical science, assistant professor, assistant professor Department of information technology and systems, The National Metallurgical Academy of Ukraine. 